\title{
Toward a recalibrated human right to a clean and healthy environment: making the conceptual transition
}

\author{
Burns H Weston \\ Rights, The University of Iowa, USA \\ David Bollier \\ Co-founder, Commons Strategies Group, Amherst, Massachusetts, USA
}

Bessie Dutton Murray Distinguished Professor of Law Emeritus and Senior Scholar, Center for Human

\begin{abstract}
Despite many noble efforts to champion the right to a clean and healthy environment and related regulation, the official recognition and jurisdictional reach of this right is highly limited. It does not matter if it is understood as an entitlement derived from other substantive rights, as a substantive right autonomous unto itself, or as a cluster of procedural entitlements. Our highly decentralized and far too voluntarist international legal order is far more concerned with privileging commercial imperatives than in protecting human rights and environmental values. However, we may be approaching a 'Grotian Moment' that presents an unusual opening for change. A variety of civil resistance movements, new sorts of Internet-based collaboration and governance, and dissenting schools of thought in economics, environmental stewardship and human rights, are gaining both credibility and adherents - locally, nationally, regionally, globally, and points in between. This convergence points to a new paradigm of law, economics, and governance that could provide a practical new way to reframe the human right to environment as the human right to commons- and rights-based ecological governance - what we call 'Green Governance.' Unlike the right to environment now practiced - theoretically appealing but troublingly indeterminate operationally - the human right to Green Governance would be anchored in a cognizably well-defined, rich history of both substantive and procedural justice. As we explain, Green Governance can provide a powerful means for challenging the Statel Market's structural limitations by drawing upon the power of Human Rights, Vernacular Law, and Self-Organized Governance as a complement or substitute for State-based governance. A human right to Green Governance could help protect the creations of nature and related societal institutions that we inherit jointly and freely from our forebears, hold in trust for future generations and seek to manage democratically in accordance with human rights principles. To advance this vision, we offer a Universal Covenant Affirming a Human Right to Commons- and Rights-based Governance of Earth's Natural Wealth and Resources, a declaration ready for immediate adoption by and for all levels of concerned society worldwide.
\end{abstract}

Keywords: ecological survival, ecological governance, commons, human rights, biocentrism, cooperation, subsidiarity, precaution, ecocide, anthropocentrism, neoliberal hegemony, competition 


\section{INTRODUCTION}

In our recently published book, Green Governance, ${ }^{1}$ we detailed the international legal status of the human right to a clean and healthy environment as currently conceived and practiced. ${ }^{2}$ In so doing, we learned a hard truth. Despite many noble efforts championing the right internationally, whether understood as an entitlement derived from other substantive rights, as a substantive right autonomous unto itself, or as a cluster of procedural entitlements, its standing in the current State sovereignty system is essentially limited in official recognition and jurisdictional reach. While that system is unquestionably in historic decline, its surrogate policy- and decision-making elites who define the substance and procedure of human rights simply have yet to recognize the combined hard and soft law authority on which the right is said to stand sufficiently to count as law universally or, indeed, as international law at all. ${ }^{3}$

The proof is in the environmental pudding. At least since Rachel Carson's Silent Spring ${ }^{4}$ humankind's squandering of nonrenewable resources, its careless disregard of precious life species, and its overall contamination and degradation of delicate ecosystems has been well known. Yet the right to environment, like much of environmental law generally, has had little more than marginal impact upon these blasphemies. In the last decade or so, indeed, we have watched nature's defilement assume systemic dimensions with almost no legal intervention whatsoever. Climate change and its begetters march on virtually unrestrained. Buoyed by capital surpluses not easily reinvested in ordinary production streams and egged on by governments lusting for larger GNPs, business enterprises have fiercely commercialized countless resources once considered beyond the reach of technology and markets, including large swaths of the land mass, the oceans, major aquifers, the orbital paths of space, and much else. And they continue to do so, essentially unabated. David Bollier has called this great, unacknowledged scandal of our time a 'silent theft' and 'the private plunder of our common wealth. ${ }^{5}$

There is not space sufficient here to account for all the doctrinal rationales put forward - parts discerning and bromide - to explain why the right to environment and related regulatory processes have failed so greatly in these respects. What must not be left unacknowledged, however, is the inescapable fact that most of the world's major

1. Burns H Weston and David Bollier, Green Governance: Ecological Survival, Human Rights, and the Law of the Commons (Cambridge University Press, Cambridge and New York 2013) [hereinafter 'Green Governance']. This article is adapted and, due to space limitations, condensed from Chapter 4 . For factually validating footnotes omitted in this condensation, see the authorities cited in Chapter 4.

2. See especially Addendum in Green Governance, supra n 1, at 281-332 (2013). In that study and herein as well, we use the phrase 'clean and healthy environment' to encapsulate the numerous adjectives that, alone or in combination, are used to identify or define this right, e.g., 'adequate,' 'decent,' 'balanced,' 'biodiverse,' 'resilient,' 'safe,' 'sustainable,' and 'viable,' in addition to 'clean' and 'healthy.' In no way, however, should this or other abbreviated usages (e.g., 'human right to environment,' 'right to environment') be interpreted to diminish the right from its fullest protective meaning.

3. But see David R Boyd, The Environmental Rights Revolution (UBC Press, Vancouver 2012) Chapter 3 documenting growing recognition of the right to environment in national (and implicitly subnational) constitutions.

4. Rachel Carson, Silent Spring (Fawcett Crest, New York 1962).

5. See David Bollier, Silent Theft: The Private Plunder of Our Common Wealth (Routledge, New York 2003). 
industrial powers simply do not support the legal (as opposed to moral) recognition of the right to environment and related regulation - China and the United States, the world's two largest greenhouse gas emitters, among them. ${ }^{6}$ Yet nonsupport is far more widespread than this, at least to the extent that it may be measured by a nation's failure or refusal to constitutionalize the right to environment; as of this writing, 100 countries (mostly developing countries, but including also prominent developed countries) have no such constitutional provision. ${ }^{7}$ In addition, a majority of the G-20 countries and approximately half the world's top 33 economies fail to meet this standard of support. Nonsupport correlates closely with advanced economies that are operationally if not also ideologically committed to neoliberal economic dealing, domestically and internationally. ${ }^{8}$

None of this should surprise. In our highly decentralized and far too voluntarist international legal order, it is the commercial and statist imperatives of the contemporary global political-economy that repeatedly trump human rights and environmental values. Indeed, as long as ecological governance remains in the grip of essentially unregulated (liberal or neoliberal) capitalism - responsible for most of the plunder and theft of our ecological wealth over the last century and a half - there never will be a human right to environment widely honoured across the globe in any official sense, least of all an autonomous one as currently, essentially loosely, conceived. Incredible though it may seem, too many otherwise sophisticated people appear incapable of understanding that our official national and international legal orders are structurally organized to contribute to the deterioration of the natural world, not to prevent it. ${ }^{9}$

The roots of this failing run deep. They are reinforced and legitimized by the Scientific Revolution as embodied in the works of Copernicus, Bacon, Galileo, Descartes, and Newton; and perhaps even sanctified by the Reformation's religious anthropocentrism which encouraged humans to see themselves as separate from nature - as its masters/beneficiaries, not its servants/stewards. As long as these worldviews prevail, the mainstream economic and political paradigm will not take the right to environment seriously; it will remain an idiosyncratic influence at best. ${ }^{10}$

We of course recognize that worldviews cannot be summarily swept aside. At the same time, however, we believe we are at a moment in history when fundamental change appears seriously afoot worldwide. A variety of civil resistance movements, new sorts of Internet-based collaboration and governance, and dissenting schools of thought in economics, environmental stewardship and human rights are gaining both credibility and adherents - locally, nationally, regionally, globally, and points

6. See, e.g., Boyd, supra n 3, at 53-7 (Table 3.2).

7. Id. Concededly, 44 of the 100 countries recognize a governmental duty of environmental protection. But a governmental duty is not, clearly, an individual or civil society right, at least not in the absence of a guaranteed right to enforce the governmental duty.

8. Of course, a failure or refusal to embrace a treaty or constitutional endorsement of the right to environment does not necessarily spell a State's lack of attention to environmental well-being any more than does a treaty or constitution that solemnly proclaims the right to ensure its implementation.

9. Elizabeth Kolbert of The New Yorker puts it crisply: 'It may seem impossible to imagine that a technologically advanced society could choose, in essence, to destroy itself, but that is what we are now in the process of doing.' Elizabeth Kolbert, Field Notes from A Catastrophe: Man, Nature and Climate Change (Bloomsbury, New York 2006) 189.

10. It must be added that neither Soviet-based communism nor Chinese-style State capitalism has shown an ability to transcend this way of thinking and governing any more than the capitalist West. 
in between. We are, we believe, at a 'Grotian Moment'11 that presents an unusual opening in our legal and political culture for advancing new ideas for effective and just environmental protection.

In this spirit, we propose a right to environment driven by a model of ecological governance that historically has proven itself capable of such protection in practice: commons- and rights-based ecological governance. We call this practice 'Green Governance,' and the right to support it, logically, 'the Human Right to Commons- and Rights-based Ecological Governance' (or the 'Human Right to Green Governance'). The value of Green Governance lies in the potential of commons for using and protecting all the creations of nature and related societal institutions that we inherit jointly and freely from our forebears, hold in trust for future generations, and manage democratically in keeping with human rights principles grounded in respect for nature as well as human beings. The value of a human right to such governance is that, unlike the right to environment now practiced - theoretically appealing but troublingly indeterminate operationally - it is anchored in a cognizably well-defined, rich history of both substantive and procedural justice.

Typically, the Commons consists of non-State management and control of natural wealth and resources governed principally according to the 'unofficial' norms, institutions, and procedures that a defined community of natural persons devises on its own to manage its common wealth inclusively and equitably, directly or by delegation. While Green Governance usually operates independently of the State or the need to be State sanctioned, in appropriate circumstances, the State may act as a guardian or trustee for it or formally facilitate its principles and practices by establishing commons-like State institutions to manage publicly owned natural wealth and resources.

But even when assisted by economic reforms and the best green technology, Green Governance and a human right to it will not succeed vis-à-vis the myriad eco-crises of our time unless people everywhere are allowed and encouraged to develop qualitatively different relationships with nature and each other - to move from anthropocentrism to biocentrism. And to this end must be cultivated both an ethic of respect for nature, sufficiency, interdependence, shared responsibility, and fairness, and a logic of integrated global and local citizenship that insists on transparency and accountability in all activities that affect the integrity of the environment.

We believe that Green Governance and its cognate human right can fulfill this ethic and logic. Properly handled, they can move us beyond the neoliberal State and Market alliance (what we call the 'State/Market'), an intimate collaboration that is chiefly responsible for the current, failed paradigm of ecological governance. They can give rise, indeed, to a new Commons Sector, operating in complement to the State and Market, that could reinvent some of the fundamental ways we orient ourselves to, and manage, natural ecosystems.

But how do we achieve this new/old paradigm of ecological governance and its supportive right? How do we enlarge our understanding of 'value' in economic thought to take account of natural capital and social well-being? How do we expand our sense of human rights and how they can serve strategic as well as moral purposes?

11. The phrase, harking back to Hugo Grotius's seventeenth-century reformation of 'the law of nations,' comes from Richard Falk, 'On the Recent Further Decline of International Law' in AR Blackshield (ed), Legal Change: Essays in Honour of Julius Stone (Butterworths, Sydney 1983) 272: 'a time in which a fundamental change in circumstances [signals] the need for a different world structure and a different international law.' 
How do we liberate ourselves from State-centric models of legal process and honour the power of nonmarket participation, local context, and social diversity in structuring economic activity and addressing environmental problems? How, in short, do we make the transition?

Let us consider here how we might make at least the conceptual transition to the new paradigm, leaving to our book a more detailed overview of how we might operationalize Green Governance in real time. ${ }^{12} \mathrm{We}$ of course do not presume to have all the answers in this regard. But we do recommend three foundational and interrelated tasks - understood also as precepts - that we believe, for Green Governance and our proposed right to it alike, are critical to the evolutionary challenge of redesigning our mental operating systems and moving forward:

1. Embrace anew the power of human rights to effect progressive change, especially when re-envisioned as a more theoretically inclusive, operationally grounded force;

2. Persuade State Law to honour the environmentally germane moral convictions and social practices that emanate from the everyday life of ecological commons (what we call the 'Vernacular Law' of the commons ${ }^{13}$ ); and

3 . Promote new policy structures and procedures that encourage and reward distributed, self-organized governance and bottom-up innovation as elements of complex systems (in contrast to bureaucratically driven, top-down forms of 'command-and-control' regulation). We call this precept 'Self-Organized Governance and Collaboration in Complex Adaptive Systems.'

We believe that, in combination, these transitional and foundational tasks or precepts can promote socio-ecological practices capable of improving the biodiversity and sustainability of the planet and enhancing the well-being of all life on it, present and future.

We also believe, as previously signaled, that it is important to reimagine and establish the human right to environment in a form and substance different from current incarnations. The new inclusive human right to commons- and rights-based ecological governance we propose constitutes such a right, embracing as it does structural and procedural issues equally with normative ones, thereby better integrating with people's everyday social and production experiences and practices. Moreover, it does not privilege any right or cluster of rights (liberty, equality, or solidarity rights) over another except as a particular fact or context warrants. It does, however, affirm what Sam Adelman might call a 'meta right' - 'a foundational right that would, where necessary, take precedence over other rights' notwithstanding the problematic of 'a hierarchy at odds with the assertion that all rights are equal and indivisible.' ${ }^{14}$ Alternatively put, it affirms a 'species right' ('a new category of ... right which transcends traditional categorizations, highlights the truly universal nature of the threat, and which we hold not simply as individual human beings but rather by virtue of our membership [in] the species homo sapiens. ...').

12. See Chs. 7-8 and Epilogue in Green Governance, supra $\mathrm{n} 1$.

13. For an elaborated definition and elucidation of 'Vernacular Law,' see infra § B at 92-9. 14. Sam Adelman, 'Rethinking Human Rights: The Impact of Climate Change on the Dominant Discourse' in Stephen Humphreys (ed), Human Rights and Climate Change (Cambridge University Press, Cambridge 2010) 173. Out of respect for all life on Earth, however, it would be helpful to view the species homo sapiens living among all other species. 
This meta or species right should be treated, we believe, with the sanction of State Law, both national and international. It embodies the spirit of Article 28 of the Universal Declaration of Human Rights ('Everyone is entitled to a social and international order in which the rights and freedoms set forth in this Declaration can be fully realized'). ${ }^{15}$ It resonates with the United Nations Declaration on the Right and Responsibility of Individuals, Groups and Organs of Society to Promote and Protect Universally Recognized Human Rights and Fundamental Freedoms. ${ }^{16}$ It complements - indeed, reinforces and extends - the values and policies embedded in the understandably popular Aarhus Convention on Access to Information, Public Participation in Decision-Making and Access to Justice in Environmental Matters. ${ }^{17}$ And, most importantly, it makes way for a sensibly collaborative and nonproprietary alternative to the ecologically dysfunctional State/Market regulatory system at the heart of our worldwide environmental crisis, lending support to commons-based governance practices that invite stakeholder engagement and innovation. It is, in sum, credible as well as necessary and thus politically attractive.

In other words, in contrast to the right to environment espoused to date, the human right to commons- and rights-based ecological governance we propose gives reason for genuine optimism. True, most people accept the existing global State/Market system as a given; they therefore do not seek to transition away from it (except marginally). But absent an overhaul of the current regulatory framework or a radical shift from it, as confirmed by environmental and human rights specialists now beginning to confront the systemic as well as jurisprudential barriers to change, ${ }^{18}$ no alternative approach is likely to prove sufficient over the long term. As Adelman convincingly argues, there is no getting around the need to confront 'the enduring pre-eminence of the principle of [territorial] sovereignty in the international system' ${ }^{19}$ and 'the notion that the market is a private sphere subject to different rules from the public domain of politics.' 20

Let us be blunt: neither the State nor the Market has been very successful at setting limits on Market activity because neither wants to. Setting limits on State/Market exploitation of nature is seen to slow economic growth, diminish profits and reduce

15. Universal Declaration of Human Rights, G.A. Res. 217(III)A, U.N. GAOR, 3d Sess., 1st plen. mtg., U.N. Doc. A/810, at 71 (10 December 1948) [hereinafter 'UDHR'], reprinted in Burns H Weston and Jonathan C Carlson (eds) (1994-) III International Law and World Order: Basic Documents [hereinafter 'Basic Documents'], available at <http://nijhoffonline. nl/subject?id=ILWO $>$ accessed 6 June 2013, at III.A.1.

16. G.A. Res. 53/144, Annex, U.N. GAOR, 53d Sess, Supp. No. 49, (Vol. 1), UN Doc A/RES/53/144, at 261 (8 March 1999) (adopted without recorded vote). Article 7 provides that '[e]veryone has the right, individually and in association with others, to develop and discuss new human rights ideas and principles and to advocate their acceptance.'

17. UNECE Convention on Access to Information, Public Participation in Decision-Making and Access to Justice in Environmental Matters, 25 June 1998, 2161 U.N.T.S 447, U.N.Doc. ECE/CEP/43, reprinted in 38 I.L.M. 517 (1999) and V Basic Documents, supra n 15, at V.B.20. 18. See, in particular, Alyson C Flournoy and David M Driesen (eds), Beyond Environmental Law: Policy Proposals for a Better Environmental Future (Cambridge University Press, Cambridge and New York 2010); Dinah Shelton, 'Equitable Utilization of the Atmosphere: A Rights-based Approach to Climate Change?', in Humphreys (ed), supra n 14 at 91; Linda Hajjar Leib, Human Rights and the Environment: Philosophical, Theoretical and Legal Perspectives (Martinus Nijhoff Publishers, Leiden and Boston 2011).

19. Adelman, supra n 14, at 167.

20. Id., at 162 . 
tax revenues. We believe, however, that a right to environment, calibrated to promote and protect commons- and rights-based ecological governance and therefore attentive to the three foundational and interrelated tasks or precepts of Human Rights, Vernacular Law, and Self-Organized Governance upon which such governance depends, affords a powerful means for challenging the State/Market's structural limitations, especially at this historical time. ${ }^{21}$

\subsection{The power of human rights}

Here, in some detail, we explain why a human rights approach to ecological governance can be powerful for both achieving Green Governance and administering it.

\subsubsection{Human rights as 'trumps'}

In his germinal book Taking Rights Seriously, legal philosopher Ronald Dworkin asserts unequivocally - and correctly - that when a claimed value or good is categorized as a right it 'trumps' most if not all other claimed values or goods. ${ }^{22}$ By framing perceived environmental entitlements as human rights, rights-holders (e.g., commoners) can assert maximum claims on society, juridically more elevated than commonplace standards, laws, or other policy choices which, in contrast to human rights, are subject to everyday revision and rescission for lack of such ordination. A proximate analogy is the distinction between a contractual or statutory claim and a constitutional one. Alexander Kiss and Dinah Shelton write: 'The moral weight this concept [of rights] affords exercises an important compliance pull ${ }^{23}$ - in no small measure because scores of them derive from the world's many religions, an association that is particularly apparent when it comes to the natural environment and environmental rights. Human rights steeped in religious tradition exercise, for obvious reasons, an especially strong compliance pull. Importantly for present purposes, they also provide powerful motivation for ardent political discourse and engagement.

Thus, when human abuse of a natural resource or ecosystem is designated the wronging of a right, or when a proposed new meta right - to Green Governance, for example - is authoritatively recognized as such, there results an opportunity for empowerment and mobilization that otherwise is lacking. A rights-based approach to ecological governance enhances the status of environmental interests when balanced against competing objectives, granting such interests formal legal and political legitimacy.

In sum, rights are not matters of charity, a question of favor or kindness to be bestowed or taken away at pleasure. They are high-level public order values or

21. Accord, Boyd, supra n 3, at 27-33 ('The Promise of a Constitutional Right to a Healthy Environment').

22. Ronald Dworkin, Taking Rights Seriously (Harvard University Press, Cambridge MA 1977) 91-3, 189-91, 269.

23. For a comprehensive overview, see, e.g., Faiths and Ecology, ARC-Alliance of Religions and Conservation, available at <http://www.arcworld.org/faiths.htm> accessed 12 January 2013, documenting the ecological views of Bahấ1, Buddhism, Christianity, Daoism, Hinduism, Islam, Jainism, Judaism, Shintoism, Sikhism, and Zoroastrianism. See also Dinah Shelton, 'Nature in the Bible' in Man and the Environment: Essays in Honor of Alexander Kiss (FrisonRoche, Paris 1998) 63, identifying where, throughout the Christian Bible, 'we are reminded that humans do not own the earth and its resources.' 
goods at the apex of public policy. They carry with them a sense of entitlement on the part of the rights-holder and obligatory implementation on the part of the rightsprotector - intergovernmental institutions, the State, society, the family. They are values or goods deemed fundamental and universal; and while not absolute, they nonetheless are judged superior to other claimed values or goods. To assert a right to freedom from degrading and otherwise abusive environmental behaviour is to strengthen the possibility of life informed by dignity and well-being. It bespeaks duty, not optional benevolence, and thus bespeaks political empowerment as well.

\subsubsection{Human rights as interdependent agents of human dignity}

Central to the concept of human rights, as just intimated, is the notion of a 'public order of human dignity,' an ordre publique 'in which values are shaped and shared more by persuasion than by coercion, and which seeks to promote the greatest production and widest possible sharing, without discriminations irrelevant of merit, of all values among all human beings. ${ }^{24}$ This notion of public order, encapsulating 'the basic policies of an international law of human dignity, ${ }^{25}$ is embedded in the International Bill of Human Rights. ${ }^{26}$

In the struggle for a clean and healthy environment, a rights-based approach to ecological governance thus signals more than environmental protection per se. It signals also that norms of nondiscrimination, justice, and dignity must be central in all aspects of ecological governance, the way in which it is achieved as well as the way in which it functions thereafter, including the manner in which it processes and resolves environmental grievances within its jurisdiction. The human right to a clean and healthy environment is part of a complex web of interdependent rights that extends protection beyond one domain to many others. Most, if not all, human rights depend on the satisfaction of other human rights for their fulfillment.

Treating freedom from abusive environmental practices as a human right thus raises the stakes against those who would damage our natural world. It recognizes, write international environmental law scholars Birnie, Boyle, and Redgwell, the 'vital character of the environment as a basic condition of life, indispensable to the promotion of human dignity and welfare, and to the fulfillment of other human rights. ${ }^{, 27}$ It thus transforms the struggle for ecological governance in the common interest into a struggle for human dignity and ecological well-being, thereby adding to the moral gravitas that makes such governance and its achievement compelling, thereby better capturing responsible attention and heightened pressure in the search for enduring solutions.

24. Myres S McDougal, 'Perspectives for an International Law of Human Dignity' in Myres S McDougal et al., Studies in World Public Order (Yale University Press, New Haven CT and Martinus Nijhoff, Dordrecht 1987) 987.

25. Myres S McDougal, Harold D Lasswell and Lung-chu Chen, Human Rights and World Public Order: The Basic Policies of an International Law of Human Dignity (Yale Unviersity Press, New Haven CT 1980) iv.

26. To wit: the 1948 Universal Declaration of Human Rights, supra n 15; the 1966 International Covenant on Economic, Social and Cultural Rights. 993 U.N.T.S. 3, art. 12(1), reprinted in III Basic Documents, supra n 15, at III.A.2; and the 1996 International Covenant on Civil and Political Rights, 993 U.N.T.S. 171, reprinted in III Basic Documents, supra n 15, at III.A.3. 27. Patricia W Birnie, Alan E Boyle, and Catherine Redgwell, International Law and the Environment (Oxford University Press, Oxford and New York 2009, $3^{\text {rd }}$ edn) $278-9$. 


\subsubsection{Human rights as a crucible for human security and democracy}

'Is not peace, in the last analysis, basically a matter of human rights,' US President John F Kennedy once famously asked, 'the right to live out our lives without fear of devastation - the right to breathe air as nature provided it - the right of future generations to a healthy existence?' ${ }^{28}$ Herein lies another, commonly overlooked virtue of human rights activism and governance. When peace is conceived as more than the absence of war, such as 'security in position, expectation, and potential with regard to all basic community values, ${ }^{29}$ then, quite obviously, 'the interrelationship of peace and human rights ... passes beyond that of interdependence and approaches that of identity. ${ }^{30}$ Peace in this sense - what today scholars like Mary Kaldor call 'human security' (emphasizing the security of the individual in contrast to that of the State, i.e., 'freedom from fear' and 'freedom from want') $)^{31}-$ becomes more or less synonymous with the fulfillment of human rights, as Kennedy suggested.

Reversing the logic, to fulfill human rights is to promote peace. Mutual respect is the foundation of peace and human security; it is also at the innermost core of all human rights. In virtually any societal context, taking human rights seriously, committing to mutual tolerance and reciprocal forbearance, even making only a good faith effort to do this, is more likely than most other stratagems to bring peace and tranquility to social order.

This is particularly true when contemplating the life-enhancing and life-sustaining qualities of Nature. Pin-pointing basic needs dependent on environmental well-being, James Quilligan observes: 'The basic reason for alleviating material insecurity through food, clean water, housing, health care, education, jobs and self-sustaining livelihoods - is to ensure people's personal safety and survival in conditions of peace and dignity. 32

As a crucible for peace or human security, in other words, human rights inspire and energize society's most respectful and cooperative instincts. At a time when even conventional representative democracy, not just autocracy, is showing itself to be appallingly dysfunctional, human rights offer a way to regenerate and reignite the democratic process, critical to addressing our portentous environmental future.

\subsubsection{Human rights as a mobilizing challenge to statist and elitist agendas}

As markers of preeminent societal values and agents of human dignity, human rights challenge and make demands on State sovereignty and power, a point that bears special notice when imagining a new human right to commons- and rights-based ecological governance. Scores of human rights conventions entered into force since World War II require States to cede bits of sovereign power in the name of human dignity.

28. John F Kennedy, A Strategy of Peace (Commencement Address at American University, 10 June 1963), available at <http://www.jfklibrary.org/Research/Ready-Reference/JFKSpeeches/Commencement-Address-at-American-University-June-10-1963.aspx > accessed 12 January 2013.

29. Myres S McDougal and Florentino P Feliciano, The International Law of War (Yale University Press, New Haven CT; Martinus Nijhoff, Dordrecht and Boston; Martinus Nijhoff, Norwell MA 1994) xviii.

30. Id.

31. See, e.g., Mary Kaldor, Human Security (Polity Press, Cambridge and Malden MA 2007).

32. James B Quilligan, 'Commons for Peace' (2011) Fall/Winter Kosmos 15. 
Legal obligations of great solemnity, many environmental charters, treaties and declarations may be counted among them - e.g., the 1972 Stockholm Declaration on the Human Environment, the 1982 World Charter for Nature, the 1986 Legal Principles for Environmental Protection and Sustainable Development adopted by the Experts Group on Environmental Law of the World Commission on Environment and Development (WCED), the 1992 Rio Declaration on Environment and Development, and the 2002 Johannesburg Declaration on Sustainable Development. ${ }^{33}$

Proof that human rights challenge and make demands on State sovereignty and power is found, too, in the many occasions in which States, intergovernmental institutions, nongovernmental organizations (NGOs), professional associations, corporations, trade unions, faith-based groups, and others have relied successfully on this 'corpus juris of social justice' ${ }^{34}$ to measure and curb State behaviour. Invoking criteria informed and refined by human rights, including environmental rights, critics question the legitimacy of political regimes, and hence their capacity to govern noncoercively or at all. The worldwide recognition of human rights as both a moral and legal beacon for assessing the actual behaviours of governments is a powerfully influential dynamic - now seen in political and market players vying to establish a 'green' public image and reputation.

To be sure, there is considerable posturing and perception gaming in efforts to claim unwarranted moral standing. But most States are keenly aware of their interdependencies. They know that, however much they may resist human rights pressures, their national interest and desired self-image depend on their willingness to play by the rules or to be perceived as doing so, especially when those rules weigh heavily on the scales of social and political morality. Even the most powerful States are vulnerable to what has come to be called 'the mobilization of shame' in defense of human rights. There is no principled reason why States that encourage or tolerate release of greenhouse gases into the atmosphere - or other abusive, degrading, or hazardous environmental practices - cannot or should not be targeted and shamed.

Not only States, however. Today, human rights claims are used increasingly to challenge and make demands on the particularist agendas of private elites. Why? Most obviously because the cross-sectoral nature and cause of much environmental degradation - the anthropogenic pollution of the atmosphere via greenhouse gases, for example - demands that industrial enterprises be held accountable. This is especially compelling when it comes to economic interests that often are more powerful than the countries within which they operate. Arguably even more importantly,

33. See Stockholm Declaration (16 June 1972), U.N. Doc. A/CONF.48/14/Rev.1 at 3, U.N. Doc. A/CONF.48/14, at 2-65; Corr 1, 1972 U.N. Jurid. Y.B. 319, reprinted in V Basic Documents, supra n 15, at V.B.3; the World Charter for Nature (28 October 1982), G.A. Res 37/7, Annex, U.N. GAOR, 37th Sess., Supp. No. 51, UN Doc A/37/51, at 17 (1983), reprinted in 22 I.L.M. 455 (1983) and V Basic Documents, supra n 15, at V.B.12; the WCED Legal Principles, see WCED Experts Group on Environmental Law, Environmental Protection and Sustainable Development: Legal Principles and Recommendations, U.N. Doc. WCED/86/23/Add.1 (1986), reprinted in V Basic Documents, supra n 15, at V.B.13; the Rio Declaration (3-14 June 1992), U.N. Doc. A/CONF.151/26 (1992), reprinted in 31 I.L.M. 874 (1992) and V Basic Documents, supra n 15, at V.B.18; and the Johannesburg Declaration (4 September 2002) <http://www.un. org/esa/sustdev/documents/WSSDPOIPD/English/POIPD.htm> accessed 12 January 2013.

34. C Van Boven, 'Survey of the Positive Law of Human Rights' in Karl Vasak (ed), (revised and edited for the English transl. by Philip Alston) 1 The International Dimensions of Human Rights (Greenwood Press, Westport CT and UNESCO, Paris 1982) 87, 88. 
human rights enshrine respect as their core value, an entitlement to equality and nondiscriminatory treatment that belongs to all human beings everywhere.

There is no question that these principles are often disregarded, much as law itself is often violated. Still, the widespread recognition of human rights across space and time places a significant moral burden, often a political and legal one as well, on those who treat other human beings in disrespectful, discriminatory ways; increasingly, similar burdens are being placed on those who mistreat the natural environment. The potential of human rights norms to dislodge or seriously burden private exclusive interests that commit and perpetuate environmental abuse is thus likewise manifest yet another persuasive reason to join the great transition.

\subsubsection{Human rights as legal and political empowerments}

As human rights carry with them a sense of entitlement on the part of the rightsholder, they embrace also a corollary 'right of the individual to know and act upon his [sic] rights' ${ }^{35}$ - a duty of satisfaction or redress on the part of the State and others to respond to right-to-know requests. The essence of human rights law is that, in Michael Freeman's pointed alert, 'if you have a right to x, and you do not get $\mathrm{x}$, this is not only a wrong, but it is a wrong against you' ${ }^{36}$ - a truth that extends inexorably to environmental rights-holders, living and unborn, principal or surrogate. And thus does the 1998 Aarhus Convention, for example, regional in intent but a model for environmental procedure everywhere, clearly state that, to protect 'the right of every person of present and future generations to live in an environment adequate to his or her health and well-being, each [State] Party shall guarantee the rights of access to information, public participation in decision-making, and access to justice in environmental matters ...., 37

Human rights facilitate this promise of empowerment in at least five distinct though interrelated ways. ${ }^{38}$ Each bears obvious relevance to environmental protection, and each also validates Cicero's great insight that 'freedom is participation in power.' 39

First, because human rights entail fundamental values of superior order, their violation correspondingly entails greater moral condemnation than do other wrongs.

35. Quoting Paragraph 7 of the 1975 Helsinki Accords, officially known as the Final Act of the Conference on Security and Co-operation in Europe: Declaration on Principles Guiding Relations Between Participating States, Respect for Human Rights and Fundamental Freedoms, Including the Freedom of Thought, Conscience, and Religion or Belief (1 August 1975), reprinted in 14 I.L.M. 1292 (1975) and I Basic Documents, supra n 15, at I.D.10. Although we wish to distance ourselves from the gendered language often found in international law discourse, we leave further quotations unamended without comment.

36. Michael DA Freeman, Human Rights: An Interdisciplinary Approach (Polity Press, Cambridge and Blackwell, Malden MA 2002) 61 (emphasis added).

37. Supra $\mathrm{n} 17$, art. 1.

38. For these attributes, we are indebted to Ronald C Slye, International Human Rights Law in Practice: International Law, Human Rights Beneficiaries, and South Africa: Some Thoughts on the Utility of International Human Rights Law, 2 Chicago Journal of International Law 59, 73-6 (2001). See also, Boyd, supra n 3, at 27-33.

39. As quoted in Marcus Tullius Cicero Quotes, Goodreads, available at <http://www.goodreads. com/quotes/show/106593> accessed 12 January 2013. 
They require therefore, a level of accountability that transcends that of other legal obligations, even to the point of criminal liability.

Second, and for the same reason, human rights help shift legal and moral burdens to redistribute power - particularly helpful when victims of harm seek to hold powerful economic and political forces accountable, typically the case in large-scale environmental crises. Framing climate change as a human rights problem, for example, helps to empower politically weaker interests with serious substantive and/or procedural claims in their struggles against the powerful.

Third, and also attributable in part to their great moral force, human rights generate legal grounds for political expression and action, as abundantly seen in the many global and regional conferences and other gatherings commonly called under the auspices of the UN and such regional organizations as the Council of Europe, the Organization of American States, and the African Union. The history of the antiapartheid movement is replete with examples. The Arab Spring and Occupy movements provide another. Increasingly under human rights banners, in formal and informal settings alike, "[t]he more fortunate are called upon to assist the less fortunate as an internationally recognized responsibility. ${ }^{, 40}$

Fourth, human rights afford access to international institutions dedicated specifically to their promotion and vindication, among them the widely accepted 'thematic mechanisms' of the UN; ad hoc tribunals relative to heinous human rights disasters; specialized treaty bodies at the global level; and the regional human rights regimes of Europe, the Americas, Africa, and lately Southeast Asia. True, the effectiveness of these institutions as enforcement mechanisms is not consistent and often they are cumbersome and time-consuming, particularly at the global level. Even when claimants do not fully succeed, however, as in the case of the Arctic Inuits suffering from global warming, for example, such institutions confirm that, given sufficient political will, perpetrators of environmental harm can be prosecuted on the international plane using formal legal tools to remedy, otherwise mitigate, or deter abuses. As Kiss and Shelton note, there is now an 'extensive jurisprudence in which the specific obligations of states to protect and preserve the environment are detailed. ${ }^{41}$ Both these formal legal tools and less formal techniques, such as civil society mobilization of shame, can deter violations of individual and group environmental rights.

Finally, human rights discourse and strategy encourage the creation of initiatives both within and beyond civil society that are designed to facilitate the meeting of basic needs. For many years, Cold War rivalries stifled such efforts for the most part. Since the 1989 fall of the Berlin Wall, however, they have proliferated, especially in the human rights NGO advocacy and scholarly communities - of profound importance because such initiatives foster the provision of basic needs, including, obviously, a clean and healthy environment. Assuring people that they have the material bases to act on their rights is the very definition of empowerment.

THERE ARE, OF COURSE, predictable objections to a rights-based strategy that would fundamentally shift the ways we currently go about governing the natural

40. Mary Robinson, 'Foreword' in Marta Santos Pais, A Human Rights Conceptual Framework for UNICEF (Innocenti Essay No. 9, UNICEF International Child Development Centre, Florence 1999), available at <http://www.unicef.org/cfc/essay-0.pdf > accessed 12 January 2013.

41. Alexander Kiss and Dinah Shelton, Guide to International Environmental Law (Martinus Nijhoff, Boston 2007) 238. 
environment. ${ }^{42}$ Five are especially conspicuous: the claimed immutability of State sovereignty, the claimed irrelevance of public international law to private actors, the claimed sanctity of corporate sovereignty, the claimed indeterminacy of human rights, and the claimed absence of human rights theory.

In our highly interdependent and interpenetrating world, it is hard to take the first three of these claims seriously, especially when applied to the global environment: the first holds little favour beyond China and Russia; the second collapsed with the 'war on terrorism'; and the third has been called repeatedly into question since the end of the Cold War and the widespread globalization of capital that followed. It is therefore unnecessary to contest these arguments here. ${ }^{43}$ The last two, however, are less obviously vulnerable and thus merit at least brief rebuttal.

\subsubsection{Rebutting the claimed indeterminacy of human rights}

Some scholars criticize the language of human rights as lacking conceptual clarity, noting that there are conflicting schools of thought as to what constitutes a right and how to define human rights. For this reason, they claim the concept to be indeterminate and therefore distrust its capacity to address real world social ills effectively or at all. They observe that there are many unresolved theoretical questions about rights, including whether the individual is the only bearer of rights (in contradistinction to such entities as families; groups of common ethnicity, religion, or language; communities; and nations); and "what rights are understood to be rights to. ${ }^{, 44} \mathrm{~A}$ certain level of well-being? A certain access to certain resources in one's life pursuit? A certain quality of opportunity in that pursuit? The relatively recent debate over 'Asian values' and its underlying tension between cultural relativist and universalist approaches to human rights make clear that all this questioning is no idle intellectual chatter. ${ }^{45}$ It is present in political discourse as well and thus serves as a possible explanation for resistance to rights-based approaches to ecological governance.

The claimed indeterminacy of human rights, however, is less problematic than it is sometimes perceived to be. The core of the human rights concept is as well-defined and articulated as is any prime social or legal prescription, a fact proven by the numerous widely accepted human rights norms increasingly enforced. Moreover, even conceding that unresolved theoretical issues relating to human rights remain, this fact does not of itself detract from the broadest and most effective actualization of the fundamental principles and values on which there is widespread agreement - for example, the human right to a clean and healthy environment.

42. For an insightful listing and assessment of such objections, see Boyd, supra $\mathrm{n}$ 3, at 33-44 ('Critiques of the Constitutional Right to a Healthy Environment').

43. But see Burns H Weston and Mark B Teerink, 'Rethinking Child Labor: A Multifaceted Human Rights Problem' in Burns H Weston (ed), Child Labor and Human Rights: Making Children Matter (Lynne Rienner Publishers, Boulder CO and London 2005) 3, 12-15 (contesting these claims at some length albeit, obviously, in the context of combating child labor).

44. Martha C Nussbaum, 'Capabilities, Human Rights, and the Universal Declaration' in Burns H Weston and Stephen P Marks (eds), The Future of International Human Rights (Transnational Publishers, Ardsley NY 1999) 25, 27 [hereinafter 'Weston and Marks'].

45. On cultural relativism versus universalism in human rights law and policy, see Burns $H$ Weston, 'The Universality of Human Rights in a Multicultured World: Toward Respectful Decision-Making' in Weston and Marks, supra n 44, at 65; Burns H Weston, 'Human Rights and Nation-Building in Cross-Cultural Settings' (2008) 60 Maine Law Review 317. 
Thus, while the concept or language of rights, like most legal language, sometimes suffers from ambiguity, it is not to be discarded simply for this reason. As with any human system, incomplete and imperfect, one must make use of those elements that are established and effective while working to improve and clarify those that remain vague or incomplete, just as we do with all other legal norms as a matter of course all the time.

\subsubsection{Rebutting the claimed absence of human rights theory}

Perhaps the most confounding of the alleged unresolved theoretical issues about human rights is the claimed absence of a theory to justify such rights in the first place. ${ }^{46}$ In the presence of ongoing philosophical and political controversy about rights in a multicultural world that does not take Christian natural law justifications of human rights for granted, one must exercise caution when adopting a human rights approach to social policy lest one be accused of cultural imperialism. It is not enough to say that human beings possess human rights simply for being human, as does, for example, the 1993 Vienna Declaration and Programme of Action, which proclaims that '[h]uman rights and fundamental freedoms are the birthright of all human beings. ${ }^{47}$ Observes Michael Freeman: 'It is not clear why one has any rights simply because one is a human being. 48

We do not disagree. But neither do we accept that there exists no theory to justify human rights in our secular times, ergo no theory to justify a human rights approach to the environment and its governance. The concept of human rights is or can be firmly established on sound theoretical grounds.

First, there is the proposition, formally proclaimed in both the 1948 Universal Declaration of Human Rights and the yet more widely adopted - and revalidating 1993 Vienna Declaration, that human rights derive from 'the inherent dignity ... of all members of the human family' ${ }^{49}$ or, alternatively, from 'the dignity and worth inherent in the human person. ${ }^{50}$ Although this proposition informs us little more than the assertion that human rights extend to human beings simply for being human, it does point the way. Unless one subscribes to nihilism, it is the human being's inherent dignity and worth that justify human rights. Of course, obvious questions remain: is human dignity and worth empirically ascertainable and, if so, how does one ascertain it?

Noteworthy in this regard is the work of Martha Nussbaum and Amartya Sen on 'capabilities and human functioning.' In their search for a theory that answers at least some of the questions raised by rights talk, they have pioneered the language of 'human capabilities' as a way to speak about, and act on, what fundamentally is required to be human - 'life,' 'bodily health,' 'bodily integrity,' 'senses, imagination,

46. The late philosopher Richard Rorty, for one, contended that there is no theoretical basis for human rights on the grounds that there is no theoretical basis for any belief. See Richard Rorty, 'Human Rights, Rationality, and Sentimentality' in Stephen Shute and Susan Hurley (eds), On Human Rights (Basic Books, New York 1993) 116, 126.

47. Vienna Declaration and Programme of Action of the World Conference on Human Rights, U.N. Doc. A/Conf.157/24, at 20-46 (5 June 1993), reprinted in 32 I.L.M. 1661 (1993) and III Basic Documents, supra n 15, at III.V.2.

48. Freeman, supra n 36, at 60-61 (emphasis in original).

49. UDHR, supra $\mathrm{n} 15$ at pmbl., para. 1 .

50. Vienna Declaration, supra n 47, at pmbl., para. 2. 
and thought,' 'emotions,' 'affiliation' ('friendship' and 'respect'), 'other species,' 'play,' and, not least, 'control over one's environment' ('political' and 'material'). ${ }^{51}$ Although Nussbaum and Sen do not reject the concept of human rights as such indeed, they see it working hand in hand with their concept of capabilities, jointly signaling the central goals of public policy - they propose an emphasis on human capabilities as the theoretical means by which to restore 'the obligation of result.' This would thereby move the discussion from the abstract to the concrete without having to rely on controversial transempirical metaphysics to cut across human differences. ${ }^{52}$

A complementary if not more fundamental theory of human rights can be found, we believe, in the idea of necessity driven by enlightened self-interest - no need to consult some transempirical source. 'A just society,' Burns Weston writes, ${ }^{53}$

whether operating across space or time or both, requires rights as a matter of necessity to guarantee its possibility. And to ensure its probability (or 'compliance pull'), it must be defined by values freely and equally chosen by its members in rational contemplation of the self-interest - their self-interest - that inheres in mutually tolerant and reciprocally forbearing attitudes and behaviours. Of course, enlightened altruism can, does, and should contribute to the building of just societies as well, and therefore should be encouraged always. But in the 'nasty, brutish, and short' Hobbesian world in which many if not most humans live, enlightened self-interest can greatly motivate respect for others. This is, indeed, the lesson that many evolutionary scientists are coming to embrace. As Martin Nowak puts it, 'our ability to cooperate goes hand in hand with succeeding in the struggle to survive.' Darwinian competition notwithstanding, individually and as a species we are more likely to survive and thrive if we honor the values that underwrite human rights law and policy in its most inclusive aspect. What goes around comes around, as they say, with the prospect of a society in waiting - local, global, present, future - that honors a public order of human dignity - the essence of human rights - marked by the widest possible shaping and sharing of all basic values among all human beings.

Such a society, we recognize, can be validated by intellectual constructs in an imagined Lockean 'initial position' - as in the Rawlsian 'veil of ignorance' construct,

51. See Martha C Nussbaum, 'Capabilities, Human Rights, and the Universal Declaration' in Weston and Marks, supra n 44, at 25, 26-7; Amartya K Sen, 'Equality of What?', Tanner Lecture on Human Values at Stanford University, Tanner Lectures on Human Values (1979). For earlier advocacy of a capabilities approach to human rights, see Bernard Williams, 'The Standard of Living: Interests and Capabilities' in Amartya K Sen, The Standard of Living (Cambridge University Press, Cambridge and New York 1987) 94; see also in Martha Nussbaum and Amartya K Sen (eds), The Quality of Life (The Belknap Press of Harvard University, Cambridge MA and London 1993).

52. This line of theoretical argument, interestingly, parallels the reason why the Commons is empowering in contemporary times: it enables individuals, as members of communities, to participate in the fulfillment of their own, most fundamental human needs and capabilities, at a time in history when a Leviathan State/Market has arrogated such functions to itself, often to the detriment of commoners. This is not to say that the modern Market and State do not need to play important (but different) roles; it is to say that human existence and the Commons are intimately bound up with each other as a matter of historical experience, and that re-validating the Commons is more likely to empower basic human capabilities and human functioning, if not grander, more elevated human aspirations as well.

53. Burns H Weston, 'The Theoretical Foundations of Intergenerational Ecological Justice: An Overview' (2012) 34 Human Rights Quarterly 251, 263-4 [footnotes omitted]. 
for example, akin to Immanuel Kant's 'categorical imperative. ${ }^{, 54}$ But we believe a preferable, more straightforward approach would be simply to postulate a just society as an empirically measurable, verifiable preference in the here and now (i.e., sans intellectual contrivance) when it is inclusively determined in the inclusive interest.

In any event, however enunciated or substantiated, the necessity idea comes down to a kind of share-and-share-alike Golden Rule. Anchored in respect and driven by selfinterest as well as empathetic altruism by all humans, present and future, it prioritizes the fundamental requirements of socioeconomic and political justice - the minimum conditions of what it means to be human, the minimum conditions for a life of human dignity in a clean, healthy, ecologically balanced, and sustainable environment.

In sum, using a human rights approach to transition to Green Governance - and making human rights a lodestar for such governance - is conceptually not difficult to comprehend or endorse. Especially when understood holistically, it can both enable and operationalize the new paradigm we propose.

What appears problematic, however, is the public's insufficient understanding of the power and potential of human rights beyond what is known by scholars, jurists, and activists who make it their specialty; the truly full human rights message has not yet reached the vast majority of the lay public worldwide. Doubtless there are many reasons for this condition. Too slavish an adherence to outmoded conceptions of human rights is certainly one of them. As historian Samuel Moyn observes, 'human rights are not so much an inheritance to preserve as an invention to remake - or even leave behind - if their program is to be vital and relevant in what is already a very different world than the one in which it came so recently. ${ }^{, 55}$

If, in other words, the environmental science is to be believed and if commons- and rights-based ecological governance is to be realistically sought on a widespread basis, then a 'bottom-up' engagement of diverse commoners and sympathetic others everywhere - concentrated in focus and strong in conviction - is required. Necessarily this must include a large-scale and sustained commitment to human rights education - as imaginatively pursued, for example, by the People's Movement for Human Rights Education (PDHRE), a New York-based NGO 'dedicated to human rights learning for social and economic transformation. ${ }^{56}$ It is, after all, life on Planet Earth that hangs in the balance.

On final analysis, then, there is no good theoretical reason why a human rights strategy should not be pursued - and many good theoretical reasons why it should. When joined to the struggle against contaminating, degrading, and otherwise abusive treatment of the natural environment, human rights can be a uniquely powerful tool for achieving as well as informing ecological governance in the common interest. Richard Hiskes puts it well. The emergence of environmental human rights, he avers, 'ushers in a new chapter in the development of human rights as a central focus of human political endeavor.' 57

54. See John Rawls, A Theory of Justice (The Belknap Press of Harvard University, Cambridge MA and London 1971) §§ 1-4, 9, 11-17, 20-30, 33-35, 39-40.

55. Samuel Moyn, The Last Utopia: Human Rights in History (The Belknap Press of Harvard University, Cambridge MA and London 2010) 9.

56. See People's Movement for Human Rights Learning <http://www.pdhre.org > accessed 12 January 2013, in particular its Human Rights Cities programme geared 'to develop and advance learning about human rights as a way of life,' See also Stephen P Marks and Kathleen A Modrowski (with Walther Lichem), 'Human Rights Cities: Civic Engagement for Societal Development' (2008) 45, available at the PDHRE website, supra.

57. Richard P Hiskes, The Human Right to a Green Future: Environmental Rights and Intergenerational Justice (Cambridge University Press, Cambridge and New York 2009) 151. 


\subsection{The potential of Vernacular Law}

'Vernacular Law,' it will be recalled, what some approximate with the term 'Wild Law, ${ }^{58}$ is the term we use to distinguish informal or unofficial law from 'State Law.' Though originating in the informal, unofficial zones of society, Vernacular Law is a source of moral legitimacy and power in its own right - which helps explain why colonial powers often sought to repress local languages in favour of their controlling mother tongues, and why postcolonial governments have done the same to consolidate the rule of their linguistic culture in multilingual settings. Such political uses of law and language point to the real power of Vernacular Law, and thus its utility in transitioning to Green Governance and the human right to it.

The terms used to describe this realm of unofficial law vary. Legal scholars have used the words 'informal,' 'customary,' 'grass-roots,' 'indigenous,' 'common,' and 'local' law. But for various reasons none of these truly satisfy. Cultural anthropologists might call it 'subaltern jurisprudence'; however, the colonial and postcolonial origins of the term 'subaltern' render it also insufficient even if illuminating.

We are concerned to emphasize the 'living law' character of this form or level of legal process - an evolving, communicative life pulse. We therefore elect the term 'Vernacular Law,' inspired by the late Ivan Illich's essays on 'Vernacular Values,' first published in CoEvolution Quarterly, and the basis of his book Shadow Work (1981). As a later commentator on Illich's essays describes it, the 'vernacular domain' evokes a 'sensibility and rootedness ... in which local life has been conducted throughout most of history and even today in a significant proportion of subsistenceand communitarian-oriented communities,' that is, 'places and spaces where people are struggling to achieve regeneration and social restoration against the forces of economic globalization. ${ }^{59}$

Yale law scholar Michael Reisman elucidates the theme in his germinal study Law in Brief Encounters, calling this neglected legal process 'microlaw. ${ }^{60}$ Especially significant for present purposes is his observation that ' $[\mathrm{w}]$ hen assessments [of formally organized legal systems] yield discrepancies between what people want and what they can expect to achieve, macrolegal changes may not be effective. Microlegal adjustments may be the necessary instrument of change. ${ }^{61}$ Reisman continues: 'In everyone's life, microlaw has not only not been superseded by state law but remains ... the most important and continuous normative experience. ${ }^{62}$ Reisman is addressing

58. See, e.g., Cormac Cullinan, Wild Law: A Manifesto for Earth Justice (Chelsea Green Publishing, White River Junction VT 2011, $2^{\text {nd }}$ edn) 30.

59. Trent Schroyer, Beyond Western Economics: Remembering Other Economic Cultures (Routledge, New York 2009) 69.

60. W Michael Reisman, Law in Brief Encounters (Yale University Press, New Haven CT 1999) 3. Reisman writes:

Mainstream contemporary legal theory - with its emphasis on the state as the centerpiece of any legal system and, for many theorists, its primary, if not exclusive, source of law misdirects our attention from the full realm of law. The law of the state may be important, but law, real law, is found in all human relations, from the simplest, briefest encounter between two people to the most inclusive and permanent type of interaction. Real law is generated, reinforced, changed, and terminated continually in the course of almost all human activity. Id.

61. Id., at 4.

62. Id. (author's emphasis). 
Vernacular Law, or the sensibilities or expectations of 'right' and 'wrong,' of 'practical' and 'ineffective,' that emerge from the everyday lives of 'ordinary' people. They may be self-conscious or unself-conscious, but the social protocols that people develop over time in a given societal setting constitute an undeniable form of law.

There are many variants. ${ }^{63}$ Three relatively conspicuous examples are the canons of the church, the rules of the sporting field, and the codes of social etiquette. At a micro extreme, Reisman includes 'looking, staring, and glaring,' 'standing in line and cutting in,' and 'rapping and talking to the boss. ${ }^{64}$ In addition, somewhere in between there exists a seemingly inexhaustible number and variety of Vernacular Law systems, each with its own protocols for what is acceptable and unacceptable, what constitutes a sanction, and other rules for negotiating relationships. These systems can be seen in the management of indigenous communities, peasant collectives, farmers' markets, businesses and factories, interbusiness dealings (e.g., 'gentlemen's agreements'), specialized trades (e.g., magicians' secrets, bakers' recipes), labor unions, academic institutions and classrooms, hospitals and wards, civil society organizations (NGOs), neighborhood associations, fraternal and sororal orders, social clubs, the family, and, obviously not to be overlooked, the commercial market and at all levels.

Vernacular Law is socially negotiated, based on practical experience, and is of great interest to us because commons governance depends critically on the informal, socially negotiated values, principles, and rules that a given community develops. It constitutes a form of cultural ballast that gives a commons stability and selfconfidence, even in the absence of formal law.

At the same time, Vernacular Law now and then acts tacitly in concert with State Law's more formal components. Indeed, subtle though the fugue of State and Vernacular Law may be, Vernacular Law - 'the most important and continuous normative experience,' says Reisman of his functionally equivalent 'microlaw' - is a cardinal process for establishing the legitimacy of State Law. It also can help adapt State Law to new human and ecological (or other) circumstances as necessary.

Perhaps the most salient arena for Vernacular Law today is the Internet - where, cyberlaw practitioner and Professor David R Johnson informed us in 2006, '[w]e are on the brink of a Cambrian explosion of differentiation of legal organisms. " ${ }^{65}$ The Internet acts as a great hosting infrastructure for countless digital commons. As it has exploded in scope and become a pervasive cultural force around the world, so Vernacular Law - self-organized, self-policing community governance - has become a default system of law in many virtual spaces (notwithstanding the lurking presence of State Law or corporate-crafted law that may enframe these commons). For millions of 'digital natives' born into a highly networked cultural environment, Vernacular Law is such a familiar, natural mode of governance that the legacy institutions of the 'real world' such as the US Congress, courts, and large corporations are seen as unduly complicated, unresponsive, and/or archaic, possibly also corrupt.

63. As Reisman puts it: 'That legal systems, like Mariushka dolls, occur within legal systems within legal systems is hardly rare. Legal anthropologists have demonstrated the prevalence, within the apparently unitary nation-state, of groups with effective political and legal organizations that are independent of and substantively different from those of the state.' Id. at 149. 64. Id., at Chs. 1, 2 and 3.

65. David Johnson, 'The Life of the Law Online,' [2006] First Monday, 6 February, at 8 , available at <http://firstmonday.org/htbin/cgiwrap/bin/ojs/index.php/fm/article/view/1314/ 1234> accessed 12 January 2013. 
As one might expect, it cannot be said that digital or other examples of Vernacular Law systems are pure in the sense that they are completely unrelated to State Law. The very idea of the uninvolved, noninterfering State itself communicates an implicit if not explicit policy of official deference and tolerance - a stance that is desirable if not indispensable for the effective governance of modern heterogeneous societies. Clearly there are times when even the tolerant State will intervene if events within these systems are perceived to compromise the dominant order; but a due regard for the opinions of 'the street,' as worked out through Vernacular Law, is essential to any system of formal law.

True, not all Vernacular Law systems are virtuous (from the vantage point of State Law at least) - e.g., black markets, inner-city gang operations, Internet pirates, and other criminal arrangements. Yet these more problematic forms of Vernacular Law cannot be summarily dismissed as criminal; quite possibly their existence may reflect the failures of State Law to meet needs that may be entirely legitimate.

The point is not, however, the number or varieties of Vernacular Law systems that can be identified. The point is that, from time to time, when the State and/or its law fails to meet the needs, wants, and expectations of the peoples they are supposed to serve, then - in Reisman's words - 'microlegal adjustments [e.g., assertions of Vernacular Law] may be the necessary instrument of change.'

No more appropriate demonstration of this truth may be found than at Runnymede in 1215 when King John of England was forced to make concessions to his feudal baron subjects in armed rebellion against his ruinous foreign policy and arbitrary rule. The resulting 'peace treaty,' the Great Charter or Magna Carta, restricted the King's absolute power and settled a number of long-standing disputes in early thirteenth-century English society. ${ }^{66}$ The terms of peace for the conflict, among many, between commoners and privatizers were spelled out in a companion document, the Charter of the Forest, adopted in 1217 by King Henry III, son and successor of King John (1166-1216). The Charter of the Forest formally recognized the Vernacular Law of the English commoners - that is, their traditional rights of access to, and use of, royal lands and forests upon which they depended for food, fuel, and economic security: their rights of pannage (pasture for their pigs), estover (collecting firewood), agistment (grazing), and turbary (cutting of turf for fuel), among other practices. Recognition of these rights also amounted to a form of protection against State terror, which the sheriff had inflicted on commoners for using the King's forests.

The Charter of the Forest was formally incorporated into the Magna Carta in $1225 ;{ }^{67}$ and, subject to minor adjustments, it remained in force from 1215 to 1971 , when it was superseded by the UK's Wild Creatures and Forest Laws Act of 1971. ${ }^{68}$ The Magna Carta, as is well known, underlies many constitutions and statutes in the English-speaking world, including in the US Constitution, the International Bill of Human Rights, ${ }^{69}$ and the principal three regional human rights conventions of Europe, the Americas, and Africa. ${ }^{70}$

66. Peter Linebaugh, The Magna Carta Manifesto: Liberties and Commons for All (University of California Press, Berkeley CA 2008) 45.

67. Id., at 39.

68. Wild Creatures and Forest Laws Act, 1971, c. 47 (Eng.).

69. Supra $\mathrm{n} 26$.

70. See European Convention for the Protection of Human Rights and Fundamental Freedoms, 4 November 1950, C.E.T.S. 5, 213 U.N.T.S. 221, reprinted in III Basic Documents, supra n 15, at III.B.8; American Convention on Human Rights, 21 November 1969, 1144 
What is most pertinent about this early history of Anglo-American law is its frank recognition of Vernacular Law as an instrument to help State Law make restorative 'macrolegal' adjustments to honour environmental needs and demands. In modern parlance, we might say that Vernacular Law provided the building blocks and feedback loops to inform the State Law enforced by the State. The social practices and traditions of commoners shape normative expectations that, if generally honoured, constitute law. As Linebaugh puts it, "[c]ommoners think first not of title deeds, but of human deeds .... Y You might call it a natural attitude. ${ }^{71}$

At the same time, if anarchy or violent confrontation is to be avoided, it cannot be assumed that restorative State Law adjustments will be made without some selfconscious intervention. Revolutions often occur precisely because State Law refuses to make necessary accommodations with Vernacular Law. As Johnson argues, law must be viewed as a living social organism, one that 'causes its own form of order and persistence ${ }^{72}$ that is capable of rejecting dysfunctional components from time to time. As a living social system, Vernacular Law does this. State Law can too easily become ossified and unresponsive over time, a captive of special interests that is made to serve narrow, private, and short-term goals.

'The problem is,' writes Johnson, 'that our current legal system lacks the most fundamental mechanism, used by more rapidly replicating and adapting biological organisms, to keep undesirable levels of complication under control. We haven't had competition for survival. ${ }^{73}$ Johnson explains:

In biology, if an organism becomes too complicated [or outmoded or corrupted] for its own good, it fails to mate and its line dies out - replaced by other systems, with other kinds of order. Because of the particular nature of law's meta-meta-story [of, by, and for the people], its historical rooting of legitimacy in a particular geographic area, we've developed only one legal organism per country. We haven't had a real competition for survival among rule sets. The competition is only between the rule of (our one) law and, presumably, anarchy. So the tendency of all rule sets to become more complicated [or outmoded or corrupted] over time, especially when written by people considering only parts of the system in analytical isolation, has not been checked by evolutionary forces. We replicate the law by telling (slightly different versions of) its story every day. ${ }^{74}$

'But,' Johnson rues, 'we tell only one story and we don't shorten the story very often because we don't have to compete very hard for our own attention. ${ }^{75}$

In her study of the history of property law, Yale law professor Carol Rose notes that custom is "a medium through which a seemingly "unorganized" public may organize itself and act, and in a sense even "speak" with the force of law ... . Over time,

U.N.T.S. 123, O.A.S.T.S. 36, OEA/Ser.L/V/II.23, Doc. 21, Rev. 6, reprinted in 9 I.L.M. 99 (1970) and III Basic Documents, supra n 15, at III.B.32; and African Charter on Human and People's Rights ('Banjul Charter'), 27 June 1981, OAU Doc. CAB/LEG/67/3/Rev. 5, reprinted in 21 I.L.M. 58 (1982) and III Basic Documents, supra n 15, at III.B.1.

71. Linebaugh, supra $\mathrm{n}$ 66, at 45 . Linebaugh continues: 'Second, commoning is embedded in a labor process; it inheres in a particular praxis of field, upland, forest, marsh, coast. Common rights are entered into by labor. Third, commoning is collective. Fourth, being independent of the state, commoning is independent also of the temporality of the law and state. Magna Carta does not list rights; it grants perpetuities. It goes deep into human history.' Id.

72. Johnson, supra n 65, at 2.

73. Id., at 7.

74. Id.

75. Id. 
communities may develop strong emotional attachments to particular places and staging particular events in those places .... ${ }^{76}$ Medieval courts were known to elevate custom over other claims, as when they upheld the right of commoners to stage maypole dance celebrations on the medieval manor grounds even after they had been expelled from tenancy.

However, courts have been hostile, generally, toward claims of traditional rights (or in our terms, rights based on Vernacular Law) because, as one court put it, they are 'forms of community unknown in this state.' Also, as creatures of the State themselves, ${ }^{77}$ they have been uneasy with the idea of informal communities as a source of law because they are not formally organized or sanctioned by the State. But as Rose observes, this is precisely why such law is so compelling and authoritative a substitute for government-made law; it reflects the people's will in direct, unmediated ways; 'it was a commonplace among British jurisprudes,' she writes, 'that a general custom, the "custom of the country," is none other than the common law itself. Looked at from this perspective, custom is the means by which an otherwise unorganized public can order its affairs, and even do so authoritatively. ${ }^{78}$

Custom thus suggests a route by which a commons may be managed - a means different from ownership by individuals or the rule of organized governments. The intriguing aspect of customary rights is that they vest property rights in groups that are indefinite and informal yet nevertheless capable of self-management. As Rose would have it, the Commons can result in a comedy (i.e., greater value creation through participation), not a tragedy.

The uppermost point to emphasize, however, is that the Vernacular Law of the Commons, particularly the ecological Commons, is a necessary instrument of change for a State/Market world order that is failing to act as a responsible steward of our planet. Through ecological and other commons, Vernacular Law is simultaneously an institution and process that safeguards common-pool resources or ecosystems while providing for an equitable distribution of the fruits borne of them. In its broad architecture, the Commons can be a paradigm of beneficent ecological governance because it can help address, among other issues, the State/Market's compulsive externalizing of costs; the ethics of monetizing all value; the growth imperatives of neoliberal economics; the legal prejudices against collective stewardship and longterm commitments; and our cultural alienation from nature. As Ugo Mattei observes, 'commons are an ecological-qualitative category based on inclusion and access' and thus create 'an institutional setting reflecting long term sustainability and full inclusion of all the global commoners, including the poorest and most vulnerable (human and non-human). ${ }^{79}$

76. Carol M Rose, 'Comedy of the Commons: Custom, Commerce, and Inherently Public Property,' in Carol M Rose, Property and Persuasion: Essays on the History, Theory, and Rhetoric of Ownership (Westview Press, Boulder CO 1994) 134.

77. As quoted in Rose, id. at 157. Rose comments, at 123-4: 'Certainly this remark reflected the general American hostility to the feudal and manorial basis of customary claims. But it also focused precisely on the informal character of the "community" claiming the right; the remark suggested that if a community were going to make claims in a corporate capacity, then the residents would have to organize themselves in a way legally authorized by the state.'

78. Id.

79. Ugo Mattei, The State, the Market, and Some Preliminary Questions about the Commons (DG III Social Cohesion of the Council of Europe project: Human Rights of People Experiencing Poverty (28 March 2011), at 5 (English version), available at <http://works.bepress.com/ ugomattei/40> accessed 12 January 2013. 
By contrast, the dominant State/Market order is an economic-quantitative paradigm of unrelenting territorial sovereignty and competitive privatism in property ownership; it produces scarcity by fostering exclusion and concentration of power in a few hands. Embracing the Vernacular Law of the ecological commons as an authoritative source of law, we submit, would prod the dominant State Law system to provide greater substantive support for Green Governance and the human right to it.

We clarify and expand upon these and other virtues of commons governance in our recently published book, Green Governance ${ }^{80}$ Suffice it to say here that the primary task of our proposed human right to commons- and rights-based ecological governance and ultimately such governance itself is not to do battle with the State or Market. It is, rather, to establish or restore effective authority and control over ecological resources at the appropriate scale, through delegations of management authority as necessary, and with distributed initiative and innovation.

It also is necessary for ecological commons to be assertive agents of normative, institutional, and procedural change, alone and in cooperation with the State and Market. Always the goal should be to advance the ethic of respect for nature, sufficiency, interdependence, shared responsibility, and fairness to the maximum extent possible; likewise the logic of an integrated global and local citizenship that insists on transparency and accountability in all environmental dealings. Additionally, commons governance should strive to ensure internally that human rights values and principles are honoured, based on the understanding that human rights and effective ecological governance go hand in hand.

\subsection{The necessity of self-organized governance and collaboration in complex adaptive systems}

Arguably the greatest challenge of all is how, even imagining how, to induce the dominant State/Market order, nationally and internationally, to recognize the need to embrace Green Governance and to cooperate in making it happen. Realistically, the 'top down' strategies favoured by guardians of the current order will reflect mostly the interests of the 'haves' over the 'have nots' and a fierce commitment to preserving the existing order. Or they will seek actually to co-opt the quest for fundamental change.

Focusing exclusively or even primarily on the formal legal order and its array of sanctioned political action is not likely to produce transformational change, however. The greatest promise lies, we believe, in 'bottom-up' or grassroots-driven approaches, especially those that are inclusive and cross-sectoral. This is not political conjecture; profound discoveries in the evolutionary sciences and the rise of complexity science over the past generation validate the power of bottom-up forms of social organization and governance. Extensive empirical research shows that some of the most robust, stable forms of governance are distributed, self-organized, and collaborative. It is thus important to survey these scientific fields, even if briefly, because they point to a different framework for understanding human agency, the evolution of cooperation, and the dynamics of governance in a networked environment.

The worldview that has prevailed for the past several centuries is familiar but archaic. As previously noted, it sees humanity as separate from Nature and posits a fairly static, mechanical outlook in which knowable causes produce measurable

80. Supra n 1, at Chs. 5-8. 
effects in linear patterns. Governance is focused on amassing the most extensive fact base and objective expert knowledge so we can devise more reliable (usually bureaucratic) systems to regulate and control isolated elements of nature or human society to our liking.

Complexity science has opened the door to some quite different frameworks for understanding human and ecological phenomena based on the observable behaviour of natural systems, not on advanced blueprints devised by brilliant minds. ${ }^{81}$ Drawing on the evolutionary lessons of chemistry and biology to identify fundamental principles governing what it calls 'complex adaptive systems,' complexity science asserts that the best systemic results will arise if intelligent, living agents are allowed to evolve over time toward optimum outcomes in suitable environments.

Frequently cited complex adaptive systems include the self-organizing dynamics and behaviours of the biosphere: microbes, ants, humans, and diverse other organisms; likewise the brain, cells, the stock market, and Internet communities. Each is nested within larger complex systems that are dynamic and constantly shifting; yet each flourishes by embodying some highly predictive theories, as distilled in schema that are useful in exploring resources and regularities in a particular environment (the 'fitness landscape'). The species with the most adaptive schema (e.g., DNA, organism functions, culture) and the most refined feedback loops will be better equipped to learn from its environment and thus adapt, evolve, and grow. Less capable agents will be shunted to niches or die, according to principles of natural selection, which evolutionary scientists increasingly believe manifests itself more at the group level than through individual organisms.

Remarkable parallels can be traced between the behaviours of natural, physical systems and social and economic ones. Relative to our quest for Green Governance specifically, they suggest that human communities can evolve into higher, more complex forms of organization without the directive control of a central sovereign or bureaucracy. Given a sufficiently defined and hospitable fitness landscape, self-organization based on local circumstances can occur. Just as biological and chemical systems exhibit autocatalytic features that generate 'order for free,' so human communities have inborn capacities to create stable order.

Indeed, this is one of the key insights of the late Nobel laureate Elinor Ostrom's empirical research of natural resource commons and the countless self-organized communities on the Internet constitute a kind of existence proof. The capacity for self-organization is often overlooked, especially by mainstream economics and its model of homo economicus. Yet commons are fully capable of yielding robust, flexible, and durable forms of managing ecological resources, in part because commons governance systems tend to arise organically from the governed themselves, in ways that are mindful of the resource, local conditions, and cultural norms. Externally imposed or arbitrary systems may or may not be as adaptive.

The point is (a) that effective ecological (and other) governance need not be imposed through a comprehensive grid of uniform general rules embodied in formal State Law and administered by centralized legislatures, regulators, and courts; and

81. Much of the pioneering work in complexity science has emerged from the Santa Fe Institute, an institute that blends physics, biology, chemistry, economics, mathematics, and the social sciences. See the Wikipedia entry for the Santa Fe Institute at $<$ https://en.wikipedia. org/wiki/Santa_Fe_Institute> accessed 12 January 2013. Leading thinkers in the field include Nobel Laureate physicist Murray Gell-Mann, psychologist and electrical engineer John Holland, economist Brian Arthur, and theoretical biologist Stuart Kauffmann. 
(b) that the right to such governance, if ultimately it is to win hearts and minds, must be commensurately informed. Complexity science demonstrates that governance can be a highly distributed, evolving form of social practice and tradition; and it can arise from the Vernacular Law that is rooted in communities of decentralized agents responding to particular local circumstances. The twentieth-century mind may be convinced that governance and organization must be based on uniform, top-down expertise and command, but the lessons of the evolutionary sciences and complexity science suggest that new modes of diversified, locally appropriate governance are entirely feasible.

These scientific perspectives suggest how we might make the conceptual transition to a Green Governance paradigm and a human right to it. First, they help us reassert the fundamental truth that human beings are part of Nature, not ahistorical supercreatures that stand apart from it and control it with a dispassionate Cartesian objectivity. Acknowledging human immersion in nature and its processes is essential if our governance institutions are to be capable of working respectfully and dynamically with Nature, rather than merely exploiting it as an Other.

Second, complexity and evolutionary sciences confirm that the most efficient and flexible systems of governance will respect the natural proclivities of lower-order governance units in a large, complex system and that coercive control from a centralized governance body without the active participation and consent of the governed at the relevant scale is ultimately futile. Subsidiarity matters. Complex, higher levels of organization are sustainable only if they take account of the elemental needs and energies of their constituent subsystems and members at all scales. The centralized mandates of an international body - relative to carbon emissions, for example - will simply be flouted and thereby fail to achieve the cooperation and compliance needed.

Finally, complexity theory offers the critical concept of emergence, which can help us understand governance in complex adaptive systems. The agents within any complex adaptive system are motivated by local circumstances and knowledge; they do not deliberately plan or create a higher, more sophisticated level of social organization. Yet, when the micro-behaviours of agents reach a critical stage of interconnection and intensity, and tap into some new flow of energy or resource, an emergent new system arises in an almost mysterious fashion.

'Living systems always seem to emerge from the bottom up, from a population of much simpler systems,' writes science journalist M Mitchell Waldrop. ${ }^{82}$ A mix of proteins, DNA, and other biomolecules coevolve to produce a cell. Neurons in the brain come together to produce cognition, emotions, and consciousness. A collection of ants self-organize into a complex ant colony. 'In the simplest terms,' complexity author Steven Johnson observes when identifying what all these systems share in common, "[complex systems] solve problems by drawing on masses of relatively stupid elements, rather than a single, intelligent "executive branch." They are bottom-up systems, not top-down. They get their smarts from below.' ${ }^{83}$ Johnson continues: 'In a more technical language, they are complex adaptive systems that display emergent behavior. In these systems, agents residing on one scale start producing behavior that lies one scale above them: ants create colonies, urbanites create neighborhoods; simple pattern-recognition software learns how to recommend new books. The

82. M Mitchell Waldrop, Complexity: The Emerging Science at the Edge of Order and Chaos (Simon \& Schuster, New York 1992) 278.

83. Steven Johnson, Emergence: The Connected Lives of Ants, Brains, Cities and Software (Scribner, New York 2001) 18. 
movement from low-level rules to higher-level sophistication is what we call emergence. ${ }^{, 84}$

Our point is that the abundant evidence of emergence in the world has important lessons for human organization, particularly since the Internet has arisen as an infrastructure for individuals to coordinate their social interactions on a global scale. The paradigmatic example is collaboratively created free and open-source software. The self-organization of tens of thousands of individual programmers, each with his or her own local motivations, propelled the emergence of a higher level of organizational complexity now known as Linux. Managed as a commons that is international in scale, the code rivals the operating systems produced by many corporate software makers.

Thanks to the Internet, a similar dynamic of emergence can be seen in the rise of Wikipedia, the Web encyclopedia now published in 285 different languages; in the open-access publishing movement, a sector of academic publishing that now produces more than 8,500 free, openly available journals; and in the Open Educational Resources (OER) movement, which produces freely available course curricula and textbooks. In the Internet era, indeed, emergence is arguably the default form of organization in forming new political movements. Bottom-up activism at the local level is capable of joining up with kindred actions in other locations, converging into something larger and more organized, with only the most minimal forms of top-down leadership and coordination. Witness in the past decade the 'flash mob' protests in South Korea; the Tahrir Square uprisings in Cairo and elsewhere since the emergence of the Arab Spring in 2011; and the M15 demonstrations in Spain protesting the illegitimacy of corporation-dominated government policy - all organized largely by cell phones.

The coalescence of local activity into more intensive, coordinated forms of advocacy at national and international levels can be seen also in activism challenging the privatization of water; the Landless Workers movement that has organized peasant farmers internationally; the Transition Town movement that seeks to re-localize economic activities in anticipation of Peak Oil and climate change; and the Pirate Party, an actual political party that arose in Sweden to fight draconian copyright laws and Internet restrictions. The party now holds two seats in the European Parliament, numerous regional and local elected positions, and it has spawned Pirate Parties in more than fifty nations.

Emergence thus constitutes what we may call a 'bottom-up' theory of governance. If agents capable of learning are allowed to co-evolve in a sufficiently hospitable fitness landscape, they can self-organize higher levels of governance and organization. This does not mean that top-down structures no longer matter, but it does mean that those structures must be capable of promoting the bottom-up capacities of lower-level agents. Honouring basic rights, freedoms, and the self-directed intelligence of individual agents in an open, flexible system (with certain necessary structures and supports), helps produce a stable, resilient system.

As should now be obvious, the science of complex adaptive systems bears certain resemblances to theories of democratic governance, but especially to the idea of the Commons as a system of ecological governance. The Commons can be seen as a class of complex adaptive systems that blend ecological forces with sociopolitical governance. Situating the Commons into the framework of complexity science helps us identify some useful principles in crafting governance systems and human rights claims relative to them. Additionally, the Commons as a complex adaptive system depends

84. Id. 
on constant, co-evolving flows of participation. As commons historian Peter Linebaugh would put it, "[t]here is no commons without commoning. ${ }^{.85}$

Complexity science teaches us that complex adaptive systems are more capable of effective ecological governance than conventional forms of top-down governance. Conventional - mostly terrestrially based - forms of governance presume they can reliably identify and control relevant boundaries, such as national borders; but in fact they fail to account for the mobile - often transnational - character of, say, the atmosphere, oceans, fish, and other wildlife, none of which respect political boundaries. UN bodies and other treaty organizations may attempt to compensate for this failure; but, rooted in the commonly inflexible, top-down priorities of the State/ Market and therefore inclined not to adapt and co-evolve, their efforts tend to be ineffectual. Indeed, for political reasons, they often shut down or punish vital feedback loops that could provide valuable information about the actual state of the environment and the efficacy of its governance.

The science of complex adaptive systems, by contrast, presumes that any given living system is open and nested within larger complex systems. Strict, controllable boundaries are not assumed, and the dream of acquiring perfect information and absolute control that the Newtonian worldview encourages and the bureaucratic mind seeks to apply is put aside. What matters instead are the co-evolving capacities of complex adaptive agents. If they can develop the inner skills and feedback loops to respond rapidly and flexibly to the fitness landscape, without producing negative externalities, they are more likely to thrive.

This is an apt description of a commons. When seen through the lens of complexity science, it is easier to understand not only how small-scale ecological commons can self-organize and function, but also how we might organize governance systems for large-scale ecological commons. The constituent parts of a complex adaptive system need respond only to local circumstances; none is required to have a comprehensive or sophisticated grasp of the larger whole to play a meaningful, essential role. The system's interconnections help solve problems that otherwise would defy the bounds of human rationality. Think, for example, of the human organism, a networked allocation of talents and responsibilities, each performing vital - but partial, local - functions, but none of them (the brain included) knowing or controlling everything. Think also of artificial intelligence in computing systems; natural and behavioural sciences researchers commonly use 'agent-based models' in networked computer systems to simulate complex situations and gain knowledge that surpasses standard modes of deduction and induction.

This metaphor is helpful for understanding commons- and rights-based ecological governance, how it can succeed, and how a human right to it should be informed. Although complex, it is a dynamic and robust way of coordinating people and managing resources. In a commons regime, it is the internal relationships across different scales and systems that matter most. Open flows of information, the development of trust, and collaborative learning help the complex adaptive system/commons flourish. What matters is not structures of control based on arrogant dreams of perfect knowledge, but structures that enable these relationships and flows of information to flourish so that bottom-up energies, innovation, and consent may manifest and generate emergent forms of new organization.

85. See Linebaugh, supra n 66 passim; see also, e.g., Peter Linebaugh, 'Some Principles of the Commons', [2010] Counterpunch 8-10 January, available at <http://www.counterpunch. org/2010/01/08/some-principles-of-the-commons> accessed 12 January 2013. 


\section{CONCLUSION}

Shifting paradigms is never easy, especially when the process implicates the many everyday elements of people's lives. In the course of human history, it is unlikely that any society, let alone all of humanity, has faced as many complex, transformational challenges in so foreshortened a timeframe as we do today. However, as outlined above, we believe that the transitional and foundational tasks or precepts of Human Rights, Vernacular Law, and Self-Organized Governance can overcome many of the deeply rooted pathologies of the State/Market system, provide practical templates for building more effective and benign ecological governance, and for these reasons help to define a recalibrated human right to environment up to the challenge of Green Governance as well as Green Governance itself.

The way forward will not be easy. Powerful economic and political forces will resist, and the architecture for change must be 'polychromatic,' with multiple, eclectic nodes of transformational change, driven by countless players around the world, in different resource domains, with different cultural perspectives. The beauty of a commons- and rights-based approach, however, is that we need not wait for the aging, ineffectual institutions of the State/Market system to take action; it can be pursued immediately among countless communities and locations around the world. Indeed, such initiatives are already underway. Our challenge is to recognize the trends pointing to a new paradigm and then to help advance them at every strategic opportunity. To this end at this stage, we offer a Universal Covenant Affirming A Human Right to Commons- and Rights-based Governance of Earth's Natural Wealth and Resources, available in this issue of this journal ${ }^{86}$ and ready for immediate adoption by any and all who seek an ecological future fit for all living things. ${ }^{87}$

86. Burns H Weston and David Bollier, 'Universal Covenant Affirming a Human Right to Commons- and Rights-based Governance of Earth's Natural Wealth and Resources' (2013) 4(2) Journal of Human Rights and the Environment 215.

87. The Universal Covenant is available in the appendix of our book, supra $\mathrm{n} 1$, and for downloading at $<$ www.commonslawproject.org $>$. 